2. Boodhwani M, Andelfinger G, Leipsic J, Lindsay T, McMurtry MS, Therrien J, et al. Canadian Cardiovascular Society position statement on the management of thoracic aortic disease. Can J Cardiol. 2014;30:577-89.

3. Erbel R, Aboyans V, Boileau C, Bossone E, Di Bartolomeo R, Eggebrecht H, et al. 2014 ESC guidelines on the diagnosis and treatment of aortic diseases: document covering acute and chronic aortic diseases of the thoracic and abdominal aorta of the adult. The task force for the diagnosis and treatment of aortic diseases of the European Society of Cardiology (ESC). Eur Heart J. 2014;35:2873-926.

4. Hiratzka LF, Bakris GL, Beckman JA, Bersin RM, Carr VF, Casey DE Jr, et al. 2010 ACCF/AHA/AATS/ACR/ASA/SCA/SCAI/SIR/STS/SVM guidelines for the diagnosis and management of patients with thoracic aortic disease: a report of the American College of Cardiology Foundation/American Heart Association task force on practice guidelines, American Association for Thoracic Surgery, American College of Radiology, American Stroke Association, Society of Cardiovascular Anesthesiologists, Society for Cardiovascular Angiography and Interventions, Society of Interventional Radiology, Society of Thoracic Surgeons, and Society for Vascular Medicine. Circulation. 2010;121:e266-369.

5. Ziganshin BA, Zafar MA, Elefteriades JA. Descending threshold for ascending aortic aneurysmectomy: is it time for a "left-shift" in guidelines? J Thorac Cardiovasc Surg. 2019;157:37-42.
See Article page 17

\section{Commentary: Cardiac surgeons adhere to societal guidelines for aortic surgery... sometimes}

\author{
Christopher Lau, MD, and Mario Gaudino, MD
}

"If all of your friends jumped off a bridge, would you jump too?" is a question that many will remember from their childhood, but the relevance of its meaning applies throughout life. In medicine and surgery, the fact that many people treat patients a certain way does not mean that it is the correct or best way. Although there is an inherent tendency to treat patients based on how our mentors did it, what our colleagues say, and what we are accustomed to, the ultimate goal is to treat patients based on scientific evidence. In this issue of the Journal, Guo and colleagues ${ }^{1}$ present the results of a survey regarding the practice patterns and indications for aortic aneurysm repair among Canadian surgeons. Although we should not deduce any information on how to treat patients from this survey, it does demonstrate the lack of equipoise among cardiac surgeons regarding criteria for aortic interventions. How much of this is due to a lack of knowledge about aortic guidelines rather than a true disagreement over which aortic

From the Department of Cardiothoracic Surgery, Weill Cornell Medicine, New York, NY.

Disclosures: The authors reported no conflicts of interest.

The Journal policy requires editors and reviewers to disclose conflicts of interest and to decline handling or reviewing manuscripts for which they may have a conflict of interest. The editors and reviewers of this article have no conflicts of interest.

Received for publication Jan 28, 2021; revisions received Jan 28, 2021; accepted for publication Jan 28, 2021; available ahead of print Feb 4, 2021.

Address for reprints: Mario Gaudino, MD, Department of Cardiothoracic Surgery, Weill Cornell Medicine, 525 East 68th St, New York, NY 10065 (E-mail: mfg9004@med.cornell.edu).

J Thorac Cardiovasc Surg 2023;165:29-30

$0022-5223 / \$ 36.00$

Copyright (c) 2021 by The American Association for Thoracic Surgery

https://doi.org/10.1016/j.jtcvs.2021.01.123
Check for updates

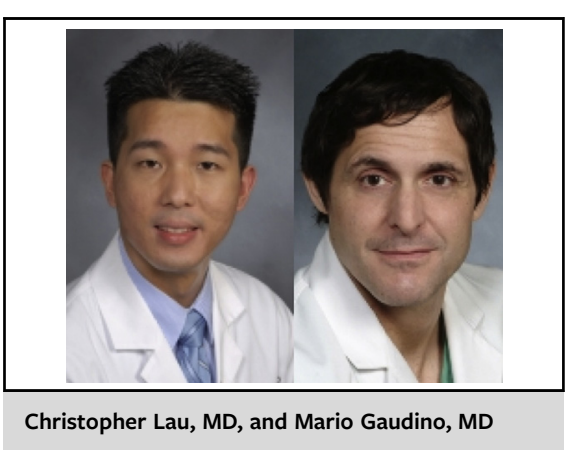

CENTRAL MESSAGE

The practice pattern and criteria

for aortic interventions vary

among cardiac surgeons, and

equipoise regarding when to

intervene is lacking.

measurement or index is the most accurate predictor of adverse aortic events is impossible to know.

A survey such as this has many limitations. In an effort to obtain as many responses as possible from all Canadian cardiac surgeons, the content of the survey is limited to lessen the burden of completing it. The authors included body surface area in the base case information, and they seem to have a predilection for using aortic size index. However, they do not include the necessary information for other aortic parameters that surgeons may use, such as aortic height index, aortic length, or cross-sectional area. $^{2}$ The individual response rate is missing nearly one-half of the surgeons, and some of those who responded performed no aortic aneurysm repairs. Whether the opinions of surgeons who do not actually treat the disease matters is debatable. Identifying information is optional to preserve privacy, so we may not know the volume or experience level of the surgeon. Finally, the authors compare high-volume and 
low-volume surgeons, but how they determined this arbitrary cutoff is not clear. Clearly, volume-outcome relationships exist among many different types of aortic surgery, but the definition of "high volume" is debatable and varies by procedure. ${ }^{3-6}$

With aortic aneurysms, knowing what our friends are doing should not necessarily inform us as to what we should be doing. Our decisions need to be based on more rigorous scientific data. Unfortunately, the level of evidence offered by a survey may be considered level D in the GRADE system: consensus (or lack thereof) among individuals who may or may not be experts in the field. The authors are correct that much debate exists in the literature regarding aortic size criteria; however, guidelines are created by experts who analyze all available data and make recommendations based on the best available evidence while minimizing the effects of individual biases. Although it is not the author's intent that this survey data should be used as evidence, the only applicable point we can take away is that more rigorous studies, such as randomized trials, would be helpful.

\section{References}

1. Guo MH, Appoo JJ, Hendry P, Masters R, Chu MWA, Ouzounian M, et al. Knowledge, attitudes, and practice preferences in the surgical threshold for ascending aortic aneurysm among Canadian cardiac surgeons. J Thorac Cardiovasc Surg. 2023; 165:17-25.e2.

2. Girardi LN, Lau C, Gambardella I. Aortic dimensions as predictors of adverse events. J Thorac Cardiovasc Surg. July 16, 2020 [Epub ahead of print].

3. Hughes GC, Zhao Y, Rankin JS, Scarborough JE, O'Brien S, Bavaria JE, et al. Effects of institutional volumes on operative outcomes for aortic root replacement in North America. J Thorac Cardiovasc Surg. 2013;145:166-70.

4. Cowan JA Jr, Dimick JB, Henke PK, Huber TS, Stanley JC, Upchurch GR Jr. Surgical treatment of intact thoracoabdominal aortic aneurysms in the United States: hospital and surgeon volume-related outcomes. J Vasc Surg. 2003;37: 1169-74.

5. Chikwe J, Cavallaro P, Itagaki S, Seigerman M, Diluozzo G, Adams DH. National outcomes in acute aortic dissection: influence of surgeon and institutional volume on operative mortality. Ann Thorac Surg. 2013;95:1563-9.

6. Stamou SC, Williams ML, Gunn TM, Hagberg RC, Lobdell KW, Kouchoukos NT. Aortic root surgery in the United States: a report from the Society of Thoracic Surgeons database. J Thorac Cardiovasc Surg. 2015;149: 116-22.e4. 